\title{
АДМІНІСТРАТИВНО-ПРАВОВА ПРОТИДІЯ МІГРАЦІЙНИМ ПРАВОПОРУШЕННЯМ
}

Сторожук І. П.

Метою цієї наукової статті $\epsilon$ визначення особливостей адміністративно-правового регулювання протидії міграційним правопорушенням. Актуальність дослідження викликана тим, що відносини у міграційній сфері тривалий час перебувають під впливом динамічних змін та потребують свого теоретичного осмислення в контексті визначення організаційноправових основ забезпечення зваженої міграційної політики та протидії наявним міграційним загрозам. Акцент на з'ясуванні адміністративно-правового аспекту протидії нелегальній міграції в практиці державних органів зумовлений універсальністю адміністративного права, дія якого поширюється на відносини державного управління у сфері міграції та прикордонної безпеки. Сформована нормативно-правова база з питань міграції має забезпечити діючий механізм протидії нелегальній міграції, а також відповідальності за порушення у цій сфері. За змістом зазначених нормативно-правових актів видно, що вони вирізняють проблему нелегальної імміграції серед інших міграційних правопорушень, передбачають протидію та профілактику цього явища, проте мають суттєвий недолік - це відсутність нормативно визначеного переліку міграційних правопорушень. Сучасний стан міграційного законодавства демонструє динамічні зміни в підходах у визначенні міграційних негараздів та способів їх подолання. Слід визнати зростання можливих протиправних проявів у міграційній сфері, що розглядається як елемент адміністративно-правової протидіі. Але повне i остаточне розв'язання такої проблеми залежить від цілого комплексу правових, організаційних і фінансових питань, які вирішуються надто повільно. У перспективі важливим буде застосування комплексного nідходу, пов'язаного з опрацюванням систематизованого нормативного документа у сфері міграції, який, можливо, охоплюватиме регулятивні, організаційноправові та правоохоронні норми.

Ключові слова: міграційні правопорушення, мігрант, протидія міграційним правопорушенням, адміністративно-правове регулювання міграційних відносин.

Storozhuk I. P. Administrative and legal counteraction to migration offenses

The purpose of this scientific article is to determine the features of administrative and legal regulation of combating migration offenses. The relevance of the study is due to the fact that relations in the field of migration have long been influenced by dynamic changes and need their theoretical understanding in the context of determining the organizational and legal framework for a balanced migration policy and counteracting existing migration threats. The emphasis on clarifying the administrative and legal aspect of combating illegal migration in the practice of public authorities is due to the universality of administrative law, the effect of which extends to the relationship of public administration in the field of migration and border security. The current legal framework on migration should provide an effective mechanism for combating illegal migration, as well as liability for violations in this area. The content of these regulations shows that they distinguish the problem of illegal immigration among other migration offenses, provide counteraction and prevention of this phenomenon, but have a significant drawback - the lack of a normatively defined list of migration offenses. The current state of migration legislation demonstrates dynamic changes in approaches to identifying migration problems and ways to overcome them. It is necessary to recognize the growth of possible illegal manifestations in the migration sphere, which is considered as an element of administrative and legal counteraction. But a complete and final solution to this problem depends on a whole range of legal, organizational and financial issues that are being resolved too slowly. In the future, it will be important to apply a comprehensive approach related to the development of a systematic normative document in the field of migration, which may cover regulatory, organizational, legal and law enforcement norms.

Key words: migration offenses, migrant, counteraction to migration offenses, administrative and legal regulation of migration relations.

Постановка проблеми. В умовах геополітичних обставин сьогодення всі держави світу значну увагу приділяють питанням удосконалення правового регулювання міграційних процесів. Для України, в світлі взятих міжнародних зобов'язань і необхідності відповідати європейським стандартам, питання вдосконалення системи державного 
управління міграційними процесами, запровадження ефективного контролю за дотриманням міграційного законодавства всередині держави, аналіз ризиків для національної безпеки є надзвичайно важливими.

Безумовно, ці питання не можуть розглядатися поза межами адміністративно-правового регулювання, яке через свій універсалізм є важливим чинником у досягненні належного захисту мігрантів та унормування діяльності органів, уповноважених підтримувати міграційний правопорядок. Протягом шести місяців 2020 року лише органами Державної міграційної служби України виявлено 2193 нелегальні мігранти, прийнято 2014 рішень про примусове повернення і в 124 випадках направлено адміністративні позови про примусове видворення. 2438 особам заборонено в'їзд в Україну [1].

Саме тому актуальними $є$ дослідження у міграційній сфері, що тривалий час перебувають під впливом динамічних змін та потребують свого теоретичного осмислення в контексті визначення організаційно-правових основ забезпечення зваженої міграційної політики та протидії наявним міграційним загрозам.

Аналіз останніх досліджень і публікацій. 3'ясування особливостей адміністративно-правового регулювання міграційних відносин, зокрема правоохоронної реакції на міграційні процеси, діяльності з протидії міграційним правопорушенням і застосування заходів примусу до іноземців та осіб без громадянства проводили такі вчені, як Н.П. Бортник, Ю.Б. Василик, В.В. Зуй, В.К. Колпаков, О.В. Кузьменко, Ю.Б. Курилюк, С.О. Мосьондз, В.І. Олефір, В.І. Палько, О.І. Піскун, В.В. Половніков, Ю.І. Римаренко, О.І. Савченко, С.Б. Чехович та інші.

Метою цієї наукової статті $є$ визначення особливостей адміністративно-правового регулювання протидії міграційним правопорушенням.

Виклад основного матеріалу дослідження. Акцент на з'ясуванні адміністративно-правового аспекту протидії нелегальній міграції в практиці державних органів зумовлений універсальністю адміністративного права, дія якого поширюється на відносини державного управління у сфері міграції та прикордонної безпеки. У процесі розбудови України як незалежної, суверенної держави було закладено правові основи щодо протидії нелегальній імміграції. На сучасному етапі національного державотворення діє низка нормативних актів, які спрямовані на реалізацію міграційної політики: закони України «Про правовий статус іноземців та осіб без громадянства», «Про біженців та осіб, які потребують додаткового або тимчасового захисту», «Про державний кордон України», «Про Державну прикордонну службу України», «Про прикордонний контроль», «Про відповідальність перевізників під час здійснення міжнародних пасажирських перевезень», «Про забезпечення прав і свобод громадян та правовий режим на тимчасово окупованій території України», «Про зовнішню трудову міграцію», «Про імміграцію». Заходи адміністративного примусу, що можуть застосовуватися до іноземців, та порядок їх реалізації визначені кодифікованими нормативно-правовими актами - Кодексом України про адміністративні правопорушення та Кодексом адміністративного судочинства України.

$\mathrm{Ha}$ підзаконному рівні нормативно-правового регулювання протидії нелегальній міграції основними суб'єктами правотворчості виступають Президент та уряд України. Їх документи спрямовані на формування та реалізацію державної міграційної політики, а також можуть стосуватися окремих питань протидії нелегальній міграції. Концептуальний зміст має Стратегія державної міграційної політики України на період до 2025 року, схвалена розпорядженням КМУ № 482-р від 12 липня 2017 року [2]. Кабінетом Міністрів України регламентовано також окремі напрями підтримання міграційного правопорядку, відповідно до його постанов, якими затверджено: Типове положення про пункт тимчасового перебування іноземців та осіб без громадянства, які незаконно перебувають в Україні (у редакції постанови КМУ № 70 від 8 лютого 2012 року); Порядок продовження строку перебування та продовження або скорочення строку тимчасового перебування іноземців та осіб без громадянства на території України (постанова КМУ № 150 від 15 лютого 2012 року); Порядок провадження за заявами іноземців та осіб без громадянства про добровільне повернення (постанова КМУ № 179 від 7 березня 2012 року); Порядок підтвердження достатнього фінансового забезпечення іноземців та осіб без громадянства для в'їзду в Україну, перебування на території України, транзитного проїзду через територію України і виїзду за ії межі та визначення розміру такого забезпечення (постанова КМУ № 884 від 4 грудня 2013 року); Правила оформлення віз для в'їзду в Україну і транзитного проїзду через її територію (постанова КМУ № 118 від 1 березня 2017 року).

Нормотворча діяльність Президента, пов'язана із рішеннями Ради національної безпеки i оборони України, які застосовуються для 
забезпечення національної безпеки, в тому числі шляхом посилення контролю за в'їздом в Україну, виїздом з України іноземців та осіб без громадянства, додержанням ними правил перебування на території України [3]; Про невідкладні заходи з нейтралізації загроз національній безпеці у сфері міграційної політики: рішення Ради національної безпеки і оборони України [4].

Сформована нормативно-правова база з питань міграції має забезпечити діючий механізм протидії нелегальній міграції, а також відповідальності за порушення у цій сфері. За змістом зазначених нормативно-правових актів видно, що вони вирізняють проблему нелегальної імміграції серед інших міграційних правопорушень, передбачають протидію та профілактику цього явища, проте мають суттєвий недолік - це відсутність нормативно визначеного переліку міграційних правопорушень.

Національне законодавство містить визначення терміна «нелегальний мігрант», яким вважається іноземець або особа без громадянства, які перетнули державний кордон поза пунктами пропуску або в пунктах пропуску, але з уникненням прикордонного контролю і невідкладно не звернулися із заявою про надання статусу біженця чи отримання притулку в Україні, а також іноземець або особа без громадянства, які законно прибули в Україну, але після закінчення визначеного їм терміну перебування втратили підстави для подальшого перебування та ухиляються від виїзду з України (п. 14 ст. 1 Закону України «Про правовий статус іноземців та осіб без громадянства») [5].

Протокол проти незаконного ввозу мігрантів по суші, морю і повітрю, який став міжнародним універсальним документом, спрямованим на протидію нелегальній міграції, визначення такого поняття не передбачає. Вживається термін «незаконний в'їзд», що згідно з п. ь ст. 3 цього Протоколу означає перетин кордонів без дотримання необхідних вимог для законного в'їзду до приймаючої держави. Цей Протокол не застосовується для кримінального переслідування мігрантів тільки через ту обставину, що вони стали об'єктом злочинних діянь [6].

У межах регіонального співробітництва було прийнято Угоду про співпрацю держав-учасниць СНД у боротьбі з незаконною міграцією 1998 року. За їі змістом простежується тлумачення таких термінів, як «незаконні мігранти», «треті держави», «держава виїзду і в’їзду» [7]. За сучасної політико-правової ситуації використання положень цього документа очевидно є обмеженим.
Встановлення переліку міграційних деліктів, за вчинення яких передбачена адміністративна відповідальність, слід розглядати як частину механізму протидії нелегальній міграції. Як такий О.В. Кузьменко пропонує розуміти функціонування взаємодіючих організаційно-структурних формувань, які з допомогою компетентнісних способів реалізують правові акти щодо протидії нелегальній міграції. На її думку, цей механізм містить у собі: 1) систему правових актів, що $є$ правовою основою функціонування взаємодіючих організаційно-структурних формувань; 2) організаційно-структурні формування протидії нелегальній міграції; 3) організаційно-правові способи протидії нелегальній міграції. Оскільки механізм протидії нелегальній міграції має всі основні системоутворюючі ознаки, це свідчить про його системний характер [8, с. 12].

Саме у системному значенні розглядає протидію нелегальній міграції Д.В. Голобородько. Аналізуючи адміністративну діяльність органів внутрішніх справ щодо протидії нелегальній міграції, дефініцію «протидія нелегальній міграції» він розкриває як систему правових та організаційних заходів, здійснюваних уповноваженими органами державної влади з метою впливу на суспільні відносини у сфері міграції, попередження, виявлення, припинення порушень міграційного законодавства, притягнення винних осіб до відповідальності, виявлення і усунення причин та умов, що сприяють нелегальній міграції [9, с. 4].

Отже, з використанням адміністративно-правових заборон небажаної міграційної поведінки формується законодавчий механізм протидії нелегальній міграції. За такого підходу важливо встановити, які діяння повинні оцінюватися як адміністративні міграційні правопорушення, що також вказуватиме на інструменти можливого правового впливу. Натепер $\epsilon$ лише теоретичні погляди щодо можливого розуміння міграційного правопорушення. Як зазначає О.І. Савченко, адміністративний делікт у сфері міграції - це суспільно небезпечне, протиправне, винне діяння (дія або бездіяльність), за вчинення якого адміністративно-деліктним законодавством у сфері міграції передбачена адміністративна відповідальність у сфері міграції. За сутністю адміністративний делікт у сфері міграції $\epsilon$ суспільно небезпечним посяганням на правовідносини, що охороняються нормами законодавства у зазначеній сфері, яким воно може заподіяти або заподіює шкоду. За змістом він є винним діянням суб'єкта адміністративної відповідальності у сфері міграції. За формою 
адміністративний делікт у сфері міграції $є$ протиправною дією або бездіяльністю, за вчинення якої передбачена адміністративна відповідальність у сфері міграції [10, с. 17].

У науковій літературі також зроблено спроби класифікувати адміністративні правопорушення міграційного характеру. Досліджуючи заходи адміністративного примусу в діяльності Державної прикордонної служби України, В.В. Половніков пропонує всі порушення законодавства про державний кордон України, боротьба з якими належить до юрисдикції цієї служби, об'єднати в дві групи. Першу групу утворюють проступки фізичних осіб, справи про які підвідомчі органам охорони державного кордону і названі у ст. 222-1 КУпАП [11]. Зокрема, до них вказаний автор відносить порушення прикордонного режиму або режиму в пунктах пропуску через державний кордон України (ст. 202 КУпАП), порушення іноземцями та особами без громадянства правил перебування в Україні і транзитного проїзду через її територію (ч. 2 ст. 203 КУпАП). Другу групу становлять проступки фізичних осіб, щодо яких Державна прикордонна служба України має право складати протоколи про правопорушення та направляти їх на розгляд інших уповноважених органів. До цієї групи, зокрема, віднесено незаконне перетинання або спробу незаконного перетинання державного кордону України (ст. 204-1). Окремою групою виділено адміністративні правопорушення юридичних осіб відповідно до норм законів, які також передбачають відповідальність за порушення правил перевезення мігрантів через кордон [12, с. 157-159]. Фактично таку ж класифікацію наведено Б.М. Марченко [13, с. 13-14].

Класифікацію деліктів, пов'язаних з нелегальною міграцією з урахуванням сучасного законодавства, в тому числі про тимчасово окуповану територію України, проводить А.Ф. Мота. Він виділяє дві групи адміністративних правопорушень, пов'язаних 3 нелегальною міграцією, протидія яким належить до компетенції Державної прикордонної служби України. Перша - це делікти, які безпосередньо $є$ нелегальною міграцією, оскільки вчиняються іноземцями або особами без громадянства і полягають у незаконному в'їзді та перебуванні на території України. Відповідальність за ці діяння передбачена статями 203, 203-1, 204-1, 204-2 та 204-4 КУпАП. До другої групи віднесено проступки, які сприяють вчиненню нелегальної міграції і $\epsilon$ або адміністративними порушеннями міграційного законодавства (ч. 3 ст. 185-3, статті 204, 205-206-1 КУпАП, а також ст. 1 Закону
України «Про відповідальність перевізників під час здійснення міжнародних пасажирських перевезень»), або порушеннями у сфері охорони державного кордону (статті 185-10 і 202 КУпАП) [14, с. 80].

Зазначені дослідження дають теоретичну уяву про коло міграційних правопорушень, щодо яких можливе застосування адміністративно-правової протидії. Однак зумовленість встановлення адміністративної відповідальності в міграційній сфері постійно перебуває під впливом намагань удосконалити міграційну політику. Ситуацію в міграційній сфері пропонується змінити шляхом невідкладного вдосконалення правових засад боротьби з нелегальною міграцією, поліпшення управління міграційними процесами, посилення юридичної відповідальності за правопорушення в цій сфері як іноземців, так і громадян України. Перелік статей КУпАП та їх диспозиції, якими встановлена адміністративна відповідальність іноземних громадян та українських громадян - фізичних і посадових осіб за порушення законодавства про правовий статус іноземців та осіб без громадянства, імовірно, зазнаватиме змін відповідно до проєкту Закону України «Про внесення змін до Кодексу України про адміністративні правопорушення щодо вдосконалення законодавства у сфері міграції» [15]. Цим документом також передбачено посилити штрафні санкції за порушення міграційного законодавства, а також встановити адміністративну відповідальність за вчинення злісної непокори законному розпорядженню чи вимозі працівника Державної міграційної служби під час виконання службових обов'язків, пов'язаних із запобіганням та протидією нелегальній (незаконній) міграції.

Висновки. Отже, сучасний стан міграційного законодавства демонструє динамічні зміни в підходах у визначенні міграційних негараздів та способів їх подолання. Слід визнати зростання можливих протиправних проявів у міграційній сфері, що розглядається як елемент адміністративноправової протидії. Адміністративно-правову заборону отримують не лише діяння іноземців та осіб без громадянства, але й осіб, у тому числі юридичних, що сприяють нелегальній міграції. Але повне і остаточне розв'язання такої проблеми залежить від цілого комплексу правових, організаційних і фінансових питань, які вирішуються надто повільно.

У перспективі важливим буде застосування комплексного підходу, пов'язаного з опрацюванням систематизованого нормативного документа в сфері міграції, який, можливо, охоплюватиме 
регулятивні, організаційно-правові та правоохоронні норми. Концептуально такий документ також повинен відображати механізм протидії міграційним правопорушенням 3 використанням як заходів адміністративної відповідальності, так i заходів, націлених на примусове повернення мігранта в країну походження чи будь-яку третю країну.

\section{Література}

1. Показники діяльності ДМС за 1 півріччя 2020 p. URL: https://dmsu.gov.ua/assets/files/ statistic/year/2020_6.pdf.

2. Стратегія державної міграційної політики України на період до 2025 року : схвалена розпорядженням Кабінету Міністрів України від 12 липня 2017 р. № 482-р. Офіційний вісник України. 2017. № 60. Ст. 1837.

3. Про посилення контролю за в'їздом в Україну, виїздом з України іноземців та осіб без громадянства, додержанням ними правил перебування на території України : рішення Ради національної безпеки і оборони України від 10 лип. 2017 р.: введене в дію Указом Президента України від 30 серп. 2017 р. № 256/2017. Урядовий кур’єр. 2017. 2 вересня.

4. Про невідкладні заходи з нейтралізації загроз національній безпеці у сфері міграційної політики : рішення Ради національної безпеки і оборони України від 1 березня 2018 р.: введене в дію Указом Президента України від 17 березня 2018 року № 72/2018. Урядовий кур'єр. 2018. 23 березня.

5. Про правовий статус іноземців та осіб без громадянства : Закон України від 22 вересня 2011 р. № 3773-VІ. Відомості Верховної Ради України. 2012. № 19-20. Ст. 179 (із змін. та допов.).

6. Протокол проти незаконного ввозу мігрантів по суші, морю і повітрю, що доповнює Конвенцію Організації Об'єднаних Націй проти транснаціональної організованої злочинності : Прийнятий резолюцією 55/25 Генеральної Асамблеї від 15 листопада 2000 р. Офіційний вісник України. 2006. № 14. Ст. 1058.

7. Угода про співпрацю держав-учасниць Співдружності Незалежних Держав в боротьбі 3 незаконною міграцією від 6 березня 1998 р. URL: http://zakon5.rada.gov.ua/laws/show/997_078.
Правове забезпечення адміністративної реформи

8. Кузьменко О.В. Адміністративно-правова протидія нелегальній міграції в Україні : автореф. дис. ... канд. юрид. наук : 12.00.07. Нац. академія внутр. справ України. Київ, 2000. 21 с.

9. Голобородько Д.В. Адміністративна діяльність органів внутрішніх справ щодо протидії нелегальній міграції : автореф. дис. ... канд. юрид. наук : 12.00.07. Дніпропетровський держ. ун-т внутр. справ. Дніпропетровськ, 2009. 21 с.

10. Савченко О. І. Адміністративні делікти у сфері міграції : автореф. дис. ... канд. юрид. наук : 12.00.07. Нац. ун-т держ. податк. служби України. Ірпінь, 2008. 26 с.

11. Кодекс України про адміністративні правопорушення : Кодекс від 07.12.1984 № 8073-X. URL: https: / zakon.rada.gov.ua/laws/show/80731-10\#Text

12. Половніков В.В. Заходи адміністративного примусу в діяльності Державної прикордонної служби України : дис. ... канд. юрид. наук : спец. 12.00.07 «Адміністративне право і процес; фінансове право; інформаційне право». Харків. нац. ун-т внутр. справ. Харків, 2007. 320 с.

13. Марченко Б.М. Адміністративна діяльність Державної прикордонної служби України : автореф. дис. ... канд. юрид. наук : спец. 12.00.07 «Адміністративне право і процес; фінансове право; інформаційне право». Дніпропетр. держ. ун-т внутр. справ. Дніпропетровськ, 2009. 21 с.

14. Мота А.Ф. Діяльність Державної прикордонної служби України з протидії нелегальній міграції (адміністративно-правовий аспект) : монографія. Хмельницький : Вид-во НАДПСУ, 2018. 492 с.

15. Проєкт Закону про внесення змін до Кодексу України про адміністративні правопорушення щодо вдосконалення законодавства у сфері міграції. № 4411 від 20.11.2020. URL: http://w1.c1.rada.gov.ua/ pls/zweb2/webproc4_1?pf3511=70497

Сторожук І. П., кандидат юридичних наук, доцент, доцент кафедри конституційного, адміністративного та фінансового права Хмельницького університету управління та права імені Леоніда Юзькова 